\title{
COMPARATIVE ANALYSIS OF ARIMA AND GARCH METHODS TO PREDICT STOCK PRICES
}

\author{
Atin Nuryatin \\ Universitas Langlangbuana, Indonesia \\ atinnuryatin20@gmail.com
}

\begin{abstract}
Investment has a very important role in economic growth, when investors invest, GDP tends to rise when investment falls, so GDP also tends to decline. Investors must be vigilant in investing in banking companies. One of the ways to predict stock prices with technical analysis is by using the ARIMA and GARCH methods. The purpose of this study is to determine whether the ARIMA and GARCH methods are accurate in predicting stock prices. The research method used in this research is descriptive and verification methods with a quantitative approach. Sources of data taken in this study are secondary data sources for the bank sub-sector found on the Indonesia Stock Exchange (IDX), namely the annual stock price reports for the years 2014, 2015, 2016, 2017, and 2018 as many as 39 companies. Processing data from this study using the ARIMA and GARCH methods with an evaluation of forecasting errors using the Root Mean Square Error (RMSE), Mean Absolute Error (MAE), or Mean Absolute Percentage Error (MAPE) analysis results using the E-View 9 program. shows that the ARIMA Method is accurate in predicting stock prices in 2015, 2016, and 2018. Meanwhile, the GARCH Method is accurate in predicting stock prices in 2014 and 2017.
\end{abstract}

Keywords: ARIMA Method, GARCH Method, Stock Price.

\section{INTRODUCTION}

The presence of capital market institutions in Indonesia adds a line of alternatives to invest in an investment. A capital market is a place for companies to seek funds to finance their business activities. Also, the capital market is a forum for investment for people who can directly invest their funds in companies that are healthy and well managed.

The development of service companies is quite rapid. This can be seen from the development of service companies listed on the Indonesia Stock Exchange, so it does not rule out the possibility that these companies are very much needed by the community and their prospects can be profitable in the present and the future.

Service companies on the IDX cover various sectors and subsectors, the bank sub-sector is one part of the financial sector service company. There is a problem that the stock of many large national banks has weakened in trading today, Thursday (26/4/2018). Banks in the category of Commercial Bank
Business Group (BUKU) IV experienced a decline in stocks. "( stocks) of all major banks fell, perhaps due to the weakening of the rupiah," said BCA President Director Jahja Setiaatmadja.

After the rupiah's depreciation was deep enough to reach Rp 15,000 per US dollar, the Composite Stock Price Index (IHSG) also weakened considerably which was followed by a flush of banking stocks. Furthermore, this condition will be exacerbated if the US central bank's benchmark interest rate, the Federal Reserve (The Fed), raises interest rates again. The Fed's strong signal to raise interest rates is large enough to even double by the end of the year.

It is predicted that if the Fed's benchmark interest rate rises, it is likely that Bank Indonesia (BI) will follow this increase which will create a negative sentiment for banking stocks if the credit margin also rises. The table below shows a list of bank sub-sector stock prices on the Indonesia Stock Exchange for the period 2014-2018. 
Table 1. List of stock prices in the subsector of banks

\begin{tabular}{|c|c|c|}
\hline Stock Code & Year & $\begin{array}{c}\text { Closing stock } \\
\text { Price (Rp) }\end{array}$ \\
\hline \multirow{5}{*}{ AGRO } & 2014 & 103 \\
\hline & 2015 & 97 \\
\hline & 2016 & 386 \\
\hline & 2017 & 525 \\
\hline & 2018 & 310 \\
\hline \multirow{5}{*}{ BBCA } & 2014 & 13125 \\
\hline & 2015 & 13300 \\
\hline & 2016 & 15500 \\
\hline & 2017 & 21500 \\
\hline & 2018 & 26000 \\
\hline \multirow{5}{*}{ BBKP } & 2014 & 750 \\
\hline & 2015 & 700 \\
\hline & 2016 & 640 \\
\hline & 2017 & 590 \\
\hline & 2018 & 272 \\
\hline \multirow{5}{*}{ BBNI } & 2014 & 6100 \\
\hline & 2015 & 4990 \\
\hline & 2016 & 5525 \\
\hline & 2017 & 9900 \\
\hline & 2018 & 8800 \\
\hline \multirow{5}{*}{ BBRI } & 2014 & 11650 \\
\hline & 2015 & 11425 \\
\hline & 2016 & 11675 \\
\hline & 2017 & 3640 \\
\hline & 2018 & 3660 \\
\hline \multirow{5}{*}{ BDMN } & 2014 & 4525 \\
\hline & 2015 & 3200 \\
\hline & 2016 & 3710 \\
\hline & 2017 & 6950 \\
\hline & 2018 & 7600 \\
\hline \multirow{5}{*}{ BJBR } & 2014 & 730 \\
\hline & 2015 & 755 \\
\hline & 2016 & 3390 \\
\hline & 2017 & 2400 \\
\hline & 2018 & 2050 \\
\hline \multirow{5}{*}{ BMRI } & 2014 & 10775 \\
\hline & 2015 & 9250 \\
\hline & 2016 & 11575 \\
\hline & 2017 & 8000 \\
\hline & 2018 & 7375 \\
\hline \multirow{5}{*}{ BNGA } & 2014 & 835 \\
\hline & 2015 & 595 \\
\hline & 2016 & 845 \\
\hline & 2017 & 1350 \\
\hline & 2018 & 915 \\
\hline \multirow{5}{*}{ BTPN } & 2014 & 3950 \\
\hline & 2015 & 2400 \\
\hline & 2016 & 2640 \\
\hline & 2017 & 2460 \\
\hline & 2018 & 3440 \\
\hline
\end{tabular}

Source: Indonesia Stock Exchange
To anticipate changes in stock prices, a stock analyst is needed. There are two types of analysis known in the world of stock investing, namely fundamental analysis and technical analysis. The difference between these two analyzes is that fundamental analysis places more emphasis on the importance of the fair value of a stock and requires a lot of data, news, and numbers, while technical analysis only requires past price and volume charts.

According to Taswan \& Soliha's opinion in Sadeq (2008), a technical analyst has a philosophy that they can find out patterns of stock price movements based on observations of stock price movements in the past. Technical analysis can also be said to be the study of market behavior which is depicted through charts to predict future price trends. Technical analysis is widely used by speculators, namely investors who buy or sell securities in the short term to look for short-term profits'.

The data used by technical analysis is market data which is historical data, such as stock price data, trading volume, and other trading information (Zulfikar, 2016). The results of Taylor \& Aller's research in Ramadhan (2015) found that more than $90 \%$ of investors gave higher weight to the use of technical analysis than fundamental analysis in buying or selling stocks. Two methods that are often used in technical analysis are the ARIMA method (Autoregressive Integrated Moving Average) method and the $\mathrm{GARCH}$ method (Generalized Autoregressive Conditional Heteroskedasticity).

According to Hartati (2018)" Arima is an integrated autoregressive moving average with each term representing the steps taken by the construction model until only random noise remains". ARIMA is one of the methods used for forecasting analysis on the type of time series data. The usefulness of forecasting to predict the future based on existing data. For certain market 
players, this is very important, because they can prepare themselves with a management strategy so that their products continue to exist in the market. (Baroroh 2008).

The ARIMA method used together with the data series is assumed to have a residual value that is constant over time, otherwise known as homoscedasticity. For ordering the forecasting model using the GARCH method, the data series is assumed to have a residual that is not constant, changes over time, this is known as heteroscedasticity.

The ARCH model differs from these assumptions. Heteroscedasticity occurs because time series data show an element of volatility. For example, the exchange rate, in a period of high volatility and high disturbance variables, follows a period where the volatility is low and the disturbance variable is also low. (Widarjono, 2018).

Robert Engle's ARCH model was later refined by the Bollerslev Team. Bollerslev stated that the disturbance variable does not exist only depending on the residual of the previous period but also the variance of the previous period's disturbance variable. If we also include the residual variance of the previous period in equation (15.4), this model is known as generalized autoregressive conditional heteroscedasticity (GARCH). Therefore the $A R C H$ model is a special case of the GARCH model.

These two methods are often used in technical analysis, namely the ARIMA method and the GARCH method. The ARIMA method is used if the data series is assumed to have a constant residual value over time, otherwise known as homoscedasticity. For the formation of a forecasting model using the $\mathrm{GARCH}$ method, the data series is assumed to have a residual that is not constant, this is known as heteroscedasticity. The proliferation of stock prices in the capital market recently has prompted many potential investors to want to know more about prospective stocks to buy for now and in the future. It takes an understanding of these purposes indepth about the stock price itself for the present and the future.

The results of Yani (2004) research on stock prices using the ARIMA method show that the ARIMA model is suitable for short-term forecasting. The results of Ramadhan (2015) research regarding the ARIMA and GARCH methods show that the GARCH model is good at predicting several stock prices compared to ARIMA. The results of the research by Nachrowi \& Hardius (2007) that predict the $\mathrm{JCl}$ movement using the ARIMA method and the GARCH method, the ARIMA method has smaller errors than the GARCH method.

From some of the studies above regarding stock price prediction using the ARIMA method and the GARCH method, it can be seen that there is an inconsistency in the results of the research which shows the accuracy of the ARIMA method only in certain periods. From this, this research will try to prove the accuracy of the ARIMA method and the GARCH method in predicting the stock price of the bank sub-sector for the 2014-2018 period.

The purpose of this study is to determine whether the ARIMA and GARCH methods are accurate in predicting stock prices. To find out the difference between the results of the ARIMA and GARCH analysis methods, the author made a study entitled "The Arima and Garch Analysis Method to Predict Stock Prices".

Based on the background that has been submitted, the hypothesis to be proposed is:

$\mathrm{H} 1=$ The ARIMA method is accurate in predicting the stock price of the bank subsector on the IDX.

$\mathrm{H} 2=$ The GARCH method is accurate in predicting the stock price of the bank subsector on the IDX.

\section{METHODS}

The research method used in this research is a descriptive method and 
verification method with a quantitative data approach measured on a numeric scale (numbers), quantitative data here is in the form of time-series data, namely data arranged according to time.

In this study, the authors conducted secondary data collection regarding stock price data taken from the sub-sector of banks listed on the Indonesia Stock Exchange for the 20141018 period. The data is in the form of time-series data, namely data per year. The population of this study is the bank subsector companies listed on the Indonesia Stock Exchange for the 20142018 period. So that the total population is 43 companies. The sampling technique used in this study was purposive sampling. The criteria determined for sampling in this study are (1) Companies listed on the Indonesia Stock Exchange, especially the banking sub-sector; (2) Companies that have complete financial statement data, especially data used in research such as stock prices.

Table 2. List of Issuers that meet the sample criteria

\begin{tabular}{ccl}
\hline No & Stock Code & \multicolumn{1}{c}{ Issuer Name } \\
\hline 1. & AGRO & Bank Rakyat Indonesia \\
2. & BBCA & Bank Central Asia Tbk \\
3. & BBKP & Bank Bukopin Tbk \\
4. & BBNI & Bank Negara Indonesia (Persero) Tbk \\
5. & BBRI & Bank Rakyat Indonesia (Persero) Tbk \\
6. & BDMN & Bank Danamon Indonesia Tbk \\
7. & BJBR & Bank Jabar Banten Tbk \\
8. & BMRI & Bank Mandiri (Persero) Tbk \\
9. & BNGA & Bank Cimb Niaga Tbk \\
10. & BTPN & Bank Tabungan Pensiunan Nasional Tbk \\
11. & BBTN & Bank Tabungan Negara (Persero) \\
12. & BBNP & Bank Nusatara Parahyangan Tbk \\
13. & BEKS & Bank Pembangunan Daerah Banten Tbk \\
14. & BINA & Bank Ina Perdana Tbk \\
15. & BJTM & Bank Pembangunan Daerah Jawa Timur Tbk \\
16. & BKSW & Bank QNB Indonesia Tbk \\
17. & BMAS & Bank Maspion Indonesia Tbk \\
18. & BNBA & Bank Bumi Arta Tbk \\
19. & BNLI & Bank Permata Tbk \\
20. & BSIM & Bank Sinar Mas Tbk \\
\hline \multicolumn{3}{c}{ Source: Indonesia Stock Exchange (2020) }
\end{tabular}

The data needed in this study is secondary data, namely data obtained and stored by a person or entity which is usually past/historical data. While the data collection technique used is documentation techniques, namely secondary data collection methods in the form of financial reports and stock trading statistics related to research obtained from the Indonesia Stock Exchange website, IDX.co.id, yahoo finance, and their respective websites. issuer.

Processing data from this study using ARIMA and GARCH methods with an evaluation of forecast errors using the Root Mean Square Error (RMSE), Mean Absolute Error (MAE), or Mean Absolute Percentage Error (MAPE) analysis results using the E-View 9 program.

After the RMSE, MAE, and MAPE values from each model are obtained, the prediction error values are compared with the following conditions: (1) If the RMSE, MAE, and MAPE values of the ARIMA model are smaller than the RMSE, MAE, and MAPE of the GARCH model, then the ARIMA model has a better performance in predicting stock prices than the GARCH method; (2) If the RMSE, MAE, and MAPE values of 
the GARCH model are smaller than the RMSE, MAE, and MAPE of the ARIMA model, then the GARCH model has a better performance in predicting stock prices than the ARIMA method.

\section{RESULTS AND DISCUSSION}

Descriptive analysis is intended to see the characteristics of the data, which in this study uses the mean, maximum value, minimum value, and standard deviation of each representative ratio.

Table 3. Statistik description

\begin{tabular}{cccccc}
\hline & $\mathbf{2 0 1 4}$ & $\mathbf{2 0 1 5}$ & $\mathbf{2 0 1 6}$ & $\mathbf{2 0 1 7}$ & $\mathbf{2 0 1 8}$ \\
& $\mathbf{( R p )}$ & $\mathbf{( R p )}$ & $\mathbf{( R p )}$ & $\mathbf{( R p )}$ & $\mathbf{( R p )}$ \\
\hline Average & 1433,308 & 1765,487 & 2008,077 & 2011,051 & 2299,744 \\
Maximum & 13,125 & 13,300 & 15,500 & 21,900 & 23,111 \\
Minimum & 23 & 53 & 50 & 50 & 50 \\
Standard Dev & 2401.828 & 3054.525 & 3460.902 & 3869,318 & 4387,551 \\
Variance & 5911933 & 9330121 & 11977842 & 14971626 & 20674248 \\
\hline \multicolumn{7}{c}{ Source: Processed data (2020) }
\end{tabular}

Based on table 3, 2015 has the largest stock sale value in the 20142018 period with a minimum annual stock price of IDR 53 but the greatest maximum value in 2018 is IDR 23111 and an average value of IDR 2299,744 with a standard deviation of 4546,894 and a variance of 20674248 . For the smallest stock sale value, namely in 2014 with an average stock price of IDR 1433,308 , a maximum value of IDR 13125 with a standard deviation of 2431,447 , and a minimum price of IDR 23.

During 2014, despite the economic slowdown, the national banking industry still showed a good and solid growth trend, as evidenced by the resilience of the banking industry which remained strong with sufficiently maintained credit, liquidity, and market risks. With the strengthening of the sale of banking stocks in 2014, the stock price was at a maximum price of $\mathrm{Rp}$. 13,125 , - with market risk of $\mathrm{Rp}$. 2401,828.-.

Banking stock performance in 2015 continued to decline, the banking stock index was minus $20.26 \%$. However, in that condition in 2015 , the value of the sale of stocks is the highest, the minimum stock price is IDR 53 , with market risk of IDR 3054,525. when compared to the previous year the price of banking stocks slightly increased. This causes a lot of investor interest in banking stocks.

In 2016, banking stocks were stable, but some banking companies still experienced a decline in stock prices. Where the stock price is still at the maximum level of IDR 15,500 with market risk of IDR 3460,902.-. Bank lending rates declined slightly in 2016, recorded at $12.04 \%$, this figure decreased slightly when compared to the previous month which was recorded at $12.16 \%$.

The banking sub-sector in 2017 experienced a fairly rapid increase with a maximum stock price of Rp. 21,900, and the market risk is Rp. 3,869, -. Many bank stocks in 2017 still attract investors, this is in line with the direction of the government which wants bank interest rates to be single digits, and becomes a positive catalyst for the movement of banking stocks 2017. With this policy, demand or demand for credit is projected to increase or be better than in 2016. The growth of stocks in the banking sub-sector this year is below the 
average growth of other industrial stocks. The growth of stocks in the banking sub-sector was only $11 \%$ or smaller than the growth of other industrial stocks which were on average above $15 \%$.

2018 will be a year of improvement again for the banking sub-sector, this is driven by a maximum stock price of IDR 23,111 and a market risk of IDR $4,387,551$. Compared to the banking sub-sector in previous years, stock prices are lower, but banking stocks in 2018 are predicted to remain attractive, in line with the ongoing economic

recovery. The economic activity of the people, which tends to increase, is expected to have a positive impact on banking performance to support these activities, although in 2017 to October BI data showed an average credit growth of only $4 \%$, several banks were able to surpass this growth individually because of loyal customers and keep maintenance. with customers to increase credit growth.

\section{ARIMA Analysis}

Table 4. ARIMA Model Estimation Results in 2014

\begin{tabular}{cccccc}
\hline Model & Constanta & AR(1) & MA(1) & $\mathbf{R}^{2}$ & F \\
\hline ARIMA $(1,0,0)$ & 18.03765 & -0.518603 & & 0.282398 & 6.886771 \\
& 0.041865 & -5.828277 & & & \\
ARIMA $(0,0,1)$ & -50.06457 & & -1.000000 & 0.570041 & 23.20154 \\
& -0.589574 & & -0.000177 & & \\
& & & & & \\
ARIMA $(1,0,1)$ & -51.67193 & -0.155721 & -1.000000 & 0.583585 & 15.88310 \\
& -0.603553 & -0.293540 & -0.000180 & & \\
\hline
\end{tabular}

Source: the results of data processing using Eviews (2020)

In the table above, it is confirmed that the method used is the ARIMA method $(1,0,1)$ with the $F$ test, the value of the coefficient of determination $R^{2}$, is greater than the other ARIMA methods.
From the forecasting using the ARIMA method $(1,0,1)$ in the attachment, the RMSE value is 2352,186 MAE of 1537,784 and MAPE is 768,2442 .

Table 5. ARIMA Model Estimation Results in 2015

\begin{tabular}{cccccc}
\hline Model & Constanta & AR(1) & MA(1) & $\boldsymbol{R}^{2}$ & F \\
\hline ARIMA & 19.08724 & -0.531820 & & 0.297166 & 7.399182 \\
$(1,0,0)$ & 0.038815 & -5.403234 & & & \\
& & & & & \\
ARIMA & -58.99494 & & -0.999999 & 0.562899 & 22.53648 \\
$(0,0,1)$ & -0.623934 & & -0.000183 & & \\
& & & & & \\
ARIMA & -60.56622 & -0.134095 & -0.998631 & 0.572971 & 15.20660 \\
$(1,0,1)$ & & -0.217142 & -0.086708 & & \\
& -0.578330 & & & &
\end{tabular}

Source: the results of data processing using Eviews (2020) 
In the table above, it is more emphasized that the method used is the ARIMA method $(0,0,1)$ with the $F$ test, the coefficient of determination $R \wedge 2$ is greater than the other ARIMA methods.
From the forecasting using the ARIMA method $(1,0,1)$, there is an attachment of the RMSE value of 3214.012 MAE of 1836.991 and MAPE of 420.5534.

Table 6. ARIMA Model Estimation Results in 2016

\begin{tabular}{cccccc}
\hline Model & Constanta & AR(1) & MA(1) & $\boldsymbol{R}^{2}$ & $\mathbf{F}$ \\
\hline ARIMA & 13.65591 & -0.529763 & & 0.294819 & 7.316322 \\
$(1,0,0)$ & 0.02372 & -5.340469 & & & \\
ARIMA & -69.16883 & & -0.999999 & 0.578912 & 24.05901 \\
$(0,0,1)$ & -0.656398 & & -0.000173 & & \\
ARIMA & -71.26107 & -0.176433 & -0.999807 & 0.595446 & 16.68106 \\
$(1,0,1)$ & -0.538630 & -0.228915 & -0.010938 & & \\
\hline
\end{tabular}

Source: the results of data processing using Eviews (2020)

In the table above, it is more emphasized that the method used is the ARIMA method $(1,0,1)$ with the $F$ test, the coefficient of determination $R \wedge 2$ is greater than the other ARIMA methods.
From the forecasting using the ARIMA method $(1,0,1)$ in the attachment, the RMSE value is 3615,540 MAE of 1970,866 and MAPE is 571,8895 .

Table 7. ARIMA Model Estimation Results in 2017

\begin{tabular}{cccccc}
\hline Model & Constanta & AR(1) & MA(1) & $\boldsymbol{R}^{2}$ & $\mathbf{F}$ \\
\hline ARIMA & 4.926257 & -0.519365 & & 0.283508 & 6.924544 \\
$(1,0,0)$ & 0.007317 & -6.798195 & & & \\
ARIMA & -78.50891 & & -0.999999 & 0.577429 & 23.91316 \\
$(0,0,1)$ & -0.482883 & & -0.000145 & & \\
ARIMA & -80.50250 & -0.169432 & -0.999136 & 0.592649 & 16.48872 \\
$(1,0,1)$ & -0.441635 & -0.290627 & -0.038234 & & \\
\hline \multicolumn{7}{c}{ Source: the results of data processing using Eviews (2020) }
\end{tabular}

In the table above, it is more emphasized that the method used is the ARIMA method $(1,0,1)$ with the $F$ test, the coefficient of determination $R \wedge 2$ is greater than the other ARIMA methods. The forecasting results using the ARIMA method $(1,0,1)$ which is attached to the
RMSE value of 4135.002 MAE of 2025.447 and MAPE of 571.2973. 
Almana : Jurnal Manajemen dan Bisnis Vol. 4 No. 3/ December 2020

ISSN 2579-4892 print/ ISSN 2655-8327 online

Table 8. ARIMA Model Estimation Results in 2018

\begin{tabular}{cccccc}
\hline Model & Constanta & $\mathrm{AR}(1)$ & $\mathrm{MA}(1)$ & $R^{2}$ & $\mathrm{~F}$ \\
\hline ARIMA & 7.916162 & -0.526840 & & 0.291781 & 7.209860 \\
$(1,0,0)$ & 0.010251 & -7.119209 & & & \\
ARIMA & -86.96174 & & -1.000000 & 0.584452 & 24.61307 \\
$(0,0,1)$ & -0.527397 & & -0.000171 & & \\
ARIMA & -89.50109 & -0.190583 & -0.998766 & 0.602809 & 17.20037 \\
$(1,0,1)$ & -0.496547 & -0.329294 & -0.054923 & & \\
\hline
\end{tabular}

Source: the results of data processing using Eviews (2020)

In the table above, it is more emphasized that the method used is the ARIMA method $(1,0,1)$ with the $F$ test, the coefficient of determination $R^{\wedge} 2$ is greater than the other ARIMA methods. From the forecasting results using the ARIMA method $(1,0,1)$ in the appendix, the RMSE value is 4856,485 MAE of 2422,408 and MAPE is 462,8757 .

Based on the results of the analysis of research conducted, there is data on stock prices in the bank subsector in 2014, the results of the data have been stationary at the level. The prediction results of the bank sub-sector stock prices during the testing period using the ARIMA model $(1,0,1)$ have a predictive error value in 2014 in the MAPE size of 768.2442. Throughout 2014 the banking sub-sector continued to decline, but this did not have a significant impact as to affect the annual stock price, which remained at a constant or stable price.

Whereas in 2015 this decline was due to the company experiencing a decline in the 2014 financial year so that it affects future stock prices with relatively constant movements, this constant stable stock price movement is suitable for ARIMA technical analysis in predicting stock prices.

In 2016 the stock price in the banking sub-sector was still said to be stable even though several companies experienced a decline but this condition did not have a major impact on the stock price of the banking sub-sector in 2016 and did not affect ARIMA technical analysis which was only influenced by the stock price that occurred at the price. Previous stocks were constant or stable which did not experience a drastic increase or decrease, ARIMA analysis is used in short-term forecasting.

For 2017, stock prices in the banking sub-sector have increased quite rapidly, the factors of this government's desire affect stock price movements, low loan interest rates at banks will increase the number of people to borrow money from banks, to stabilize stock prices with this policymaking the ARIMA method accurate in predicting stock prices.

In 2018, banking stocks are still attractive, investors believe in the prospects for the domestic banking industry going forward. This is due to the ongoing economic improvement so that the price of banking stocks continues to rise from year to year. With a constant or stable nature of experiencing a decline and increase in stock prices in the banking subsector, ARIMA analysis is used in short-term forecasting.

For short-term investors, by looking at the technical analysis ARIMA shows an increase in which the method 
is influenced by annual stock price movements that are stable or constant GARCH Analysis for stock movements.

Table 9. ARCH-LM Effect Testing Results in 2014

\begin{tabular}{|c|c|c|c|}
\hline Heteroskedasti & $\mathrm{ARCH}$ & & \\
\hline F-statistic & 1.184160 & Prob. $F(5,27)$ & 0.3429 \\
\hline Obs ${ }^{\star} R$-squared & 5.935042 & Prob. Chi-Square(5) & 0.3126 \\
\hline
\end{tabular}

Source: Processed data (2020)

Based on the calculated value $\mathrm{X}^{2}$, which is $\left(\mathrm{obs}^{\star} R^{2}\right.$ ) is equal to 5.935042 with a probability of 0.3126 or $\alpha$ is greater than $1 \%$. Thus, the slackness 37 is statistically insignificant, so we fail to reject the null hypothesis which means that the residual variance is constant or in other words the model used does not contain $\mathrm{ARCH}$ elements. From the ARCH-LM results, the model obtained is GARCH $(1,5)$. From the forecasting using the GARCH method (0.5), there is an RMSE value of 1626,950 MAE of 1155,493 and a MAPE of 599,2453 .

Table 10. ARCH-LM Effect Testing Results in 2015

\begin{tabular}{llll}
\hline \multicolumn{3}{l}{ Heteroskedasticity Test: ARCH } & \\
\hline F-statistic & 0.191175 & Prob. F(3,31) & 0.9016 \\
Obs*R-squared & 0.635765 & Prob. Chi-Square(3) & 0.8882 \\
\hline
\end{tabular}

Source: Processed data (2020)

Based on the calculated value $\mathrm{X}^{2}$, which is $\left(\mathrm{obs}^{*} R^{2}\right)$ is equal to 0.635765 with a probability of 0.88882 or $\alpha$ is greater than $1 \%$. Thus, the slackness 37 is statistically insignificant, so we fail to reject the null hypothesis which means that the residual variance is constant or in other words the model used does not contain ARCH elements. From the ARCH-LM results, the model obtained is $\operatorname{GARCH}(1,3)$. From the results of forecasting using the $\mathrm{GARCH}$ method $(1,3)$, which is attached to the RMSE value of 3572,502 MAE of 2191,054 and MAPE of 529.2350 .

Table 11. ARCH-LM Effect Testing Results in 2016

\begin{tabular}{llll}
\hline \multicolumn{3}{l}{ Heteroskedasticity Test: ARCH } & \\
\hline F-statistic & 0.190582 & Prob. F(3,31) & 0.9020 \\
Obs*R- & 0.633829 & Prob. Chi-Square(3) & 0.8886 \\
squared & & & \\
\hline
\end{tabular}

Source: Processed data (2020)

Based on the calculated value $x^{2}$, which is $\left(\mathrm{obs}^{*} R^{2}\right.$ ) is equal to 0.633829 with a probability of 0.8886 or $\alpha$ is greater than $1 \%$. Thus, the slackness 37 is statistically insignificant, so we fail to reject the null hypothesis which means that the residual variance is constant or in other words the model used does not contain ARCH elements. From the ARCH-LM results, the model obtained is GARCH $(1,3)$. From the results of forecasting using the $\mathrm{GARCH}$ method 
$(1,3)$, which is attached to the RMSE value of 4056,264 MAE of 2526,425 and MAPE of 846,7655 .

Table 12. ARCH-LM Effect Testing Results in 2017

\begin{tabular}{llll}
\hline Heteroskedasticity Test: ARCH & \\
\hline F-statistic & 0.342619 & Prob. F(10,17) & 0.9555 \\
$\begin{array}{l}\text { Obs*R- } \\
\text { squared }\end{array}$ & 4.696582 & Prob. Chi-Square(10) & 0.9105 \\
\hline
\end{tabular}

Source: Processed data (2020)

Based on the calculated value $X^{\wedge}$ 2 , which is (obs ${ }^{*} R \wedge 2$ ) it is equal to 4.696582 with a probability of 0.9105 or a greater than $1 \%$. Thus, the slackness 37 is statistically insignificant, so we fail to reject the null hypothesis which means that the residual variance is constant or in other words the model used does not contain ARCH elements. From the ARCH-LM results, the model obtained is $\operatorname{GARCH}(1,10)$. From the forecasting results using the $\mathrm{GARCH}$ method (1.10) in the appendix, the RMSE value is 2079,703 MAE of 1386,066 and MAPE is 356,0372 .

Table 13. ARCH-LM Effect Testing Results in 2018

\begin{tabular}{llll}
\hline Heteroskedasticity Test: ARCH & \\
\hline F-statistic & 8.375138 & Prob. F(5,27) & 0.0001 \\
Obs*R-squared & 20.06365 & Prob. Chi-Square(5) & 0.0012 \\
\hline
\end{tabular}

Source: Processed data (2020)

Based on the calculated value $X^{\wedge}$ 2 , which is (obs * $R \wedge 2$ ) is equal to 20.06365 with a probability of 0.0012 or a less than $1 \%$. Thus, the slackness 37 is statistically significant so that we reject the null hypothesis which means that the residual variance is constant or in other words, the model used contains the ARCH element. From the ARCH-LM results, the model obtained is $\mathrm{GARCH}$ $(1,5)$. From the forecasting results using the GARCH method (1.5) in the appendix, the RMSE value is 3243,900 MAE of 2651,907 and MAPE is 577,7444 .

Based on the results and explanations above seems like The banking sub-sector experienced a slowdown in sales in 2014 and in 2015 several banking companies experienced a downturn. The uncertainty of the stock price movement will be very sensitive in predicting future stock sports following the level of market volatility.

Banking subsector stocks in 2016 were stable, there were only a few companies that experienced a decline, resulting in an unstable rise and fall in stock prices, in 2017 the stocks of the banking sub-sector experienced a fairly rapid bullish candle (increase), this resulted in a quite drastic increase in sub-sector stock prices banks in 2017 , 2018 the stocks of the banking subsector were quite good in increasing their stock prices.

The results of the analysis of the stock price data for the bank subsector in 2014 did not contain an $\mathrm{ARCH}$ element in the data. Therefore, the GARCH method cannot be used to model data.

Based on the analysis of the data on the stock price of the bank subsector in 2015, it shows that there is no $\mathrm{ARCH}$ 
effect on the data, therefore the GARCH method is unable to model the data.

The results of the analysis of the bank subsector stock price data in 2016 did not contain an ARCH element in the data. Therefore, the GARCH method is unable to model data.

The results of the analysis of the bank subsector stock price data in 2017 did not contain an ARCH element in the data. Therefore, the GARCH method is unable to model data.

Based on the results of the analysis of stock price data for the bank subsector in 2018, it shows that there is a problem with residual heteroscedasticity. Therefore the GARCH method is used to model the volatility of the bank subsector stock returns in 2018, using the GARCH method $(1,5)$.

\section{CONCLUSION}

The ARIMA method is accurate in predicting stock prices in 2015, 2016, and 2018 which has a small error rate evaluating forecast errors using RMSE, MAE, and MAPE. Meanwhile, the GARCH method is accurate in predicting stock prices in 2014 and 2017. It has a small error rate evaluating forecast errors using RMSE, MAE, and MAPE.

\section{REFERENCES}

Baroroh, Ali. (2008). Trik Trik Analisis Statistik dengan SPSS15. Jakarta: PT Elex Media Komputindo.

Hartati, Yunita. (2018). Analisis Metode Arima dan Garch Dalam Memprediksi Harga Saham. Skripsi Universitas Langlang Buana Bandung.

Nachrowi, Nachrowi \& Hardius, Usman (2007). Prediksi IHSG dengan Model GARCH dan Model ARIMA. Jurnal Ekonomi dan Pembangunan Indonesia. 7(2).

Ramadhan Ariestya, Bayu. (2015). Analisis Perbandingan Metode Arima dan Metode Garch Untuk Memprediksi Harga Saham. Skripsi Universitas Telkom.

Sadeq, Ahmad. (2008). Analisis Prediksi Indeks Harga Saham Gabungan Metode ARIMA ( studi pada IHSG di Bursa Efek Jakarta. Tesis program studi Magister Manajemen Universitas Diponegoro.

Widarjono, Agus. (2018). Ekonometrika. Yogyakarta: UPP STIM YKPN.

Yani, Ahmad. (2004) Hubungan Keuangan Antara Pemerintah Pusat dan. Daerah. Jakarta: PT Raja Grafindo Persada.

Zulfikar. (2016). Pengantar Pasar Modal Dengan Pendekatan Statistika. Yogyakarta: Deepublish. 